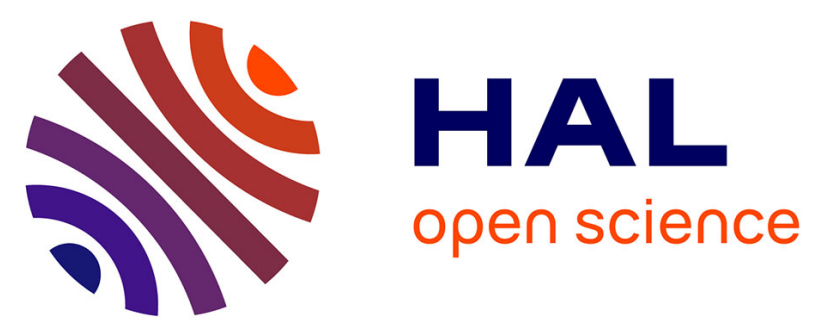

\title{
A scientific note on the lactic acid bacterial flora within the honeybee subspecies Apis mellifera (Buckfast), A. m. scutellata, A. m. mellifera, and A. m. monticola
} Tobias Olofsson, Alejandra Vásquez, Diana Sammataro, Joseph Macharia

\section{- To cite this version:}

Tobias Olofsson, Alejandra Vásquez, Diana Sammataro, Joseph Macharia. A scientific note on the lactic acid bacterial flora within the honeybee subspecies Apis mellifera (Buckfast), A. m. scutellata, A. m. mellifera, and A. m. monticola. Apidologie, 2011, 42 (6), pp.696-699. 10.1007/s13592-0110064-2 . hal-01003600

\author{
HAL Id: hal-01003600 \\ https://hal.science/hal-01003600
}

Submitted on 1 Jan 2011

HAL is a multi-disciplinary open access archive for the deposit and dissemination of scientific research documents, whether they are published or not. The documents may come from teaching and research institutions in France or abroad, or from public or private research centers.
L'archive ouverte pluridisciplinaire HAL, est destinée au dépôt et à la diffusion de documents scientifiques de niveau recherche, publiés ou non, émanant des établissements d'enseignement et de recherche français ou étrangers, des laboratoires publics ou privés. 


\title{
A scientific note on the lactic acid bacterial flora within the honeybee subspecies Apis mellifera (Buckfast), A. m. scutellata, A. m. mellifera, and $A$. m. monticola
}

\author{
Tobias C. Olofsson ${ }^{1}$, Alejandra VÁsquez ${ }^{1}$, Diana SAmmataro ${ }^{2}$, Joseph Macharia ${ }^{3}$ \\ ${ }^{1}$ Microbiology Laboratory at Campus Helsingborg, Department of Cell and Organism Biology, Lund University Campus \\ Helsingborg, Rönnowsgatan 6, PO Box SE-25108, Helsingborg, Sweden \\ ${ }^{2}$ USDA-ARS Carl Hayden Honey Bee Research Centre, Department of Entomology, University of Arizona, 2000 East Allen \\ Road, Tucson, AZ 85719, USA \\ ${ }^{3}$ Research Production and Extension, Jomo Kenyatta University of Agriculture and Technology, P. O Box 62000-00200, Nairobi, \\ Kenya
}

Received 17 August 2010 - Revised 16 February 2011 - Accepted 16 February 2011

Lactobacillus / Bifidobacterium / Apis mellifera / co-evolution / 16S rRNA genes

It was discovered by Olofsson and Vásquez (2008) that a novel lactic acid bacteria (LAB) microbiota with numerous LAB, comprising the genera Lactobacillus and Bifidobacterium, live in a symbiotic relationship with honeybees (Apis mellifera) in their honey stomach. The study was conducted in Sweden with bees bred according to the Buckfast system. A repetitive study by Vásquez et al. (2009a, b) on A. mellifera and Apis mellifera scutellata was conducted in the USA near the Carl Hayden Honeybee Research Centre (Tucson, AZ), showing a microbiota composed of the exact same bacterial phylotypes.

An erratum was later published on the latter study, stating that trinomial subspecies epithets of collected honeybees should refer to populations sampled within the endemic range of a recognized subspecies, which was not done in that case. The correct denomination for this bee source should have been African-derived A. mellifera, frequently also referred

Corresponding author: T.C. Olofsson, tobias.olofsson@cob.lu.se Manuscript editor: Klaus Hartfelder to as Africanized honeybees or New World African bees, instead of Apis mellifera scutellata. In theory, a honey stomach LAB microbiota in the Africanderived A. m. scutellata could be different from the original A. m. scutellata sampled in Africa. In the present study, a comparison of the LAB microbiota in the honey stomachs of the subspecies A. m. scutellata, Apis mellifera mellifera, Apis mellifera monticola, and the subspecies mix A. mellifera bred according to the Buckfast system was conducted. The purpose was to investigate whether subspecies of $A$. mellifera that evolved on different continents share the same phylotypes or strains of indigenous LAB microbiota in their honey stomachs. All of the bee subspecies were sampled within their respective endemic range of the recognized subspecies, except for the Buckfast bee (which is a mixture of many $A$. mellifera subspecies, primarily A. m. mellifera and Apis mellifera ligustica).

Samples of bees, fresh bee bread, bee pollen, and unripe honey from the subspecies $A$. m. scutellata and $A$. m. monticola were collected from the Kakamega rainforest, Kenya, and express shipped to Sweden. Samples from the native bee A. m. mellifera were retrieved from a conservation project in Sweden called Nordbi. We analyzed this variety of samples 
since the bees add their LAB microbiota from their honey stomach to bee pollen, bee bread (Vásquez and Olofsson 2009), and nectar during honey production (Olofsson and Vásquez 2008). From each colony, the bacterial cultivation was conducted from ten pooled honey stomachs of incoming foragers, $1.0 \mathrm{~g}$ of honey, $1.0 \mathrm{~g}$ of bee bread, and from bee pollen of the legs of five foragers. At the laboratory in Sweden, a total of 173 bacterial isolates from A. m. scutellata, A. m. mellifera, and A. m. monticola (Table I) were identified by their 16S rRNA genes (methods of Olofsson and Vásquez 2008). Seventy-three were previously identified honey bee LAB, and 27 of those were unique (Figure 1).

Previous results from 16S rRNA gene sequencing of the honey stomach LAB from the Buckfast bees were included, but not the sequences of the American samples from the same study Vásquez et al. (2009a, b) since they were nearly identical. Additionally, the American bees were not regarded as endemic $A$. mellifera subspecies.

The results revealed that all studied honeybee subspecies of $A$. mellifera probably share the same Lactobacillus and Bifidobacterium phylotypes (Figure 1). Presently, 13 phylotypes have been identified from the most extensively studied $A$. mellifera, the Buckfast bee (clusters 1 to 12 in Figure 1). Phylotypes Bin2 and Hma3 in cluster 3 are not readily separated since the main differences in the 16S rRNA gene occur in the second half of the gene, which is not used in this study. All phylotypes are represented by bacterial strains derived from two to four A. mellifera subspecies (Figure 1). Nevertheless, absent strains may be recovered by a more extensively performed study since the different phylotypes of the bees' LAB microbiota vary in numbers by the bees' health conditions, sample times, and food sources. In this study, a new Lactobacillus phylotype (cluster 11) was isolated and includes strains Fhon13 (Buckfast, Sweden) and bbt1 (A. m. scutellata, Kenya). Another novel Lactobacillus phylotype (bbr24, cluster 7) was found only from samples of $A$. m. scutellata. As expected, the similarities and divergences of the bacterial strains among the discovered LAB phylotypes seem to reflect the similarities and divergences among the bee subspecies included in this study. It points in the direction that the composition of bacterial symbionts, in this case the LAB microbiota, reflects the changes in evolution of the $A$. mellifera subspecies.

In the study of Vásquez et al. (2009a, b), phylotypes belonging to the Pasteurellaceae family were obtained from both Swedish and American honeybee samples. However, such phylotypes were not found in the present study from samples of $A$. m. scutellata, A. m. mellifera, or A. m. monticola.

One of the key issues in the present study was to clarify whether subspecies of the honeybee $A$. mellifera harbored a similar LAB microbiota within their honey stomach. As we have shown, subspecies of A. mellifera share exactly the same LAB phylotypes in their honey stomach microbiota despite the fact that Buckfast is a mix of many different $A$. mellifera subspecies and that bee subspecies from different continents were compared. Furthermore, the results indicate that A. mellifera subspecies may host subspecies-specific LAB strains. Our results display-for the first time- a plausible co-evolution of LAB symbionts as the strains within phylotypes that represent the divergences and similarities within the investigated $A$. mellifera subspecies. Yet, a more extensive sampling must be undertaken to confirm these results.

Table I. Number of identified bacterial isolates sampled from bees or bee food from the different $A$. mellifera subspecies either from colonies in an apiary or from wild colonies.

\begin{tabular}{lccccc}
\hline Bee subspecies & Honey stomach & Honey & Bee pollen & Bee bread & Number of colonies \\
\hline A. m. mellifera & 25 & 1 & 5 & 0 & 1 \\
A. m. scutellata & 33 & 21 & 0 & 24 & $1^{\text {a }}$ \\
A. m. monticola & 32 & 0 & 32 & 0 & $1^{\text {a }}$
\end{tabular}

${ }^{\mathrm{a}}$ Wild colonies 
NJ

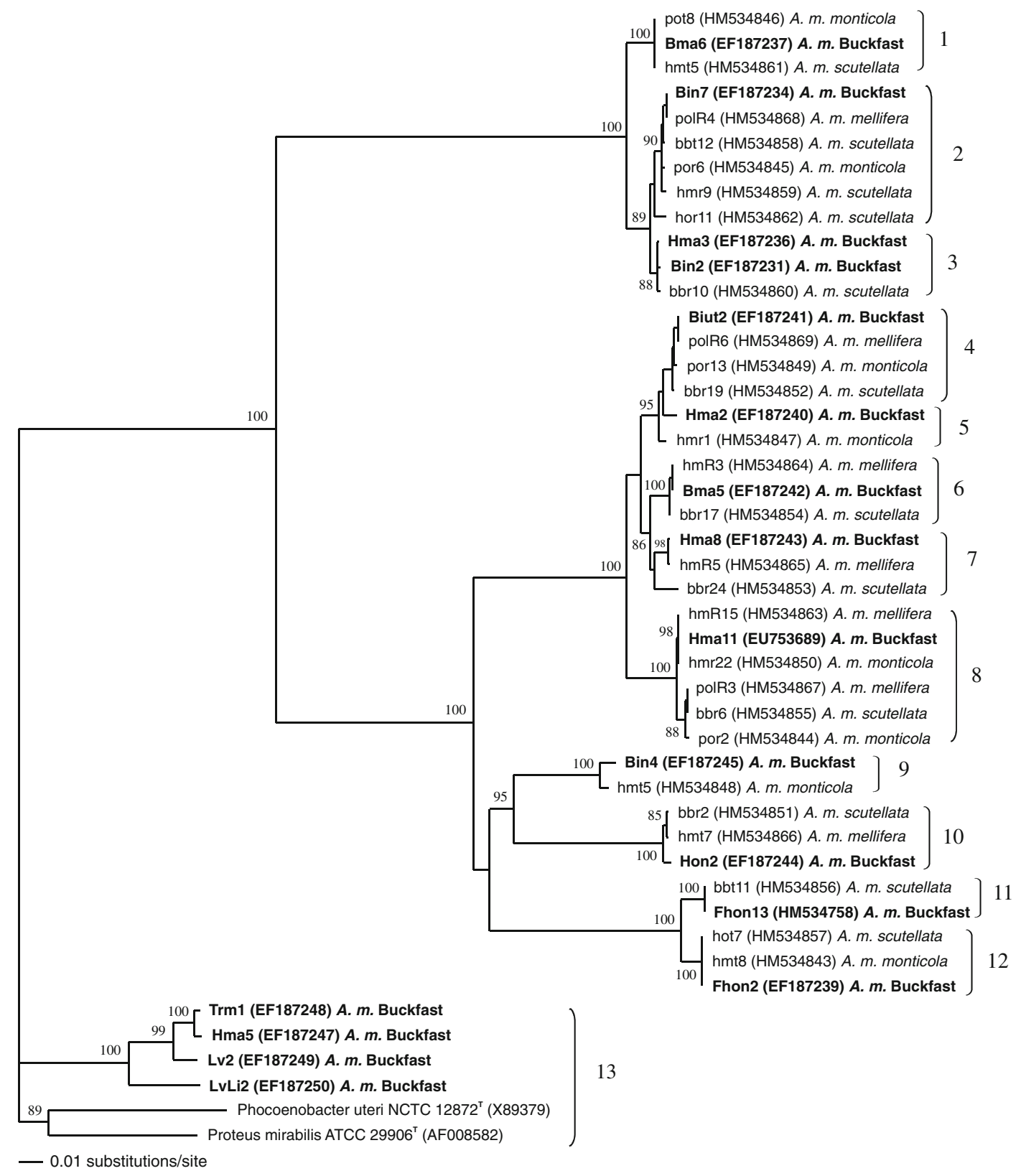

Figure 1. Phylogenetic tree based on a distance matrix analysis of 748 positions in the 16S rRNA gene. The phylotypes characterized in the previous study are displayed in bold print. Clusters 1-13 display the LAB phylotypes. Bifidobacteria is represented in clusters 1-3 and lactobacilli in clusters 4-12. The Pasteurellaceae group (cluster 13) served as the out-group. The characteristic trinominal subspecies epithets are in bold print, the accession numbers in parenthesis. Bar 5-bp changes. The bacterial 16S rRNA gene sequences were deposited in GenBank using the displayed accession numbers. 


\section{ACKNOWLEDGEMENTS}

This study was financed by Ekhagastiftelsen, SparbankstiftelsenSkåne and the Swedish Research Council Formas. We are grateful for the help of the beekeeper and project leader of Nordbi (Apis mellifera mellifera) Ingvar Arvidsson.

Flore bactérienne de l'acide lactique chez les sousespèces d'abeilles, Apis mellifera (Buckfast), A.m. scutellata, $A$. m. mellifera and $A$. m. monticola (Note scientifique)

Eine wissenschaftliche Notiz über die Milchsäurebakterienflora in Unterarten der Honigbiene, Apis mellifera (Buckfast), A. m. scutellata, A. m. mellifera und A. m. monticola

\section{REFERENCES}

Olofsson, T.C., Vásquez, A. (2008) Detection and identification of a novel lactic acid bacterial flora within the honey stomach of the honeybee Apis mellifera. Curr. Microbiol. 57, 356-363

Vásquez, A., Olofsson, T.C. (2009) The lactic acid bacteria involved in the production of bee pollen and bee bread. J. Apic. Res. 48, 189-195

Vásquez, A., Olofsson, T.C., Sammataro, D. (2009a) A scientific note on the lactic acid bacterial flora in honeybees in the USA - A comparison with bees from Sweden. Apidologie 40, 26-28

Vásquez, A., Olofsson, T.C., Sammataro, D. (2009b) A scientific note on the lactic acid bacterial flora in honeybees in the USA-A comparison with bees from Sweden. Erratum. Apidologie 40, 417 